\title{
Augmented Reality for Introducing Fuel Cell as Electrochemical Energy Conversion on Vocational School
}

\author{
https://doi.org/10.3991/ijim.v14i12.15573 \\ Siti Sendari ${ }^{(凶)}$, Mahfud Jiono, Markus Diantoro, Poppy Puspitasari, \\ Heru Suryanto \\ Universitas Negeri Malang, Jawa Timur, Indonesia \\ siti.sendari.fteum.ac.id \\ Hadi Nur \\ Universiti Teknologi Malaysia, Johor Bahru, Malaysia
}

\begin{abstract}
Nowadays, one kind of promising energy is fuel cell technology, which produces electricity while hydrogen gas flows from anode to cathode through a membrane. A single fuel cell can be integrated in series as a fuel cell stack. It shows electro-chemical process, where the gas flows from the anode to cathode through a membrane and acts as protons and electrons. Students have plenty of difficulties to understand the concept of the electro-chemical process. Thus, this paper studies the effectiveness of usability of the developed augmented reality (AR) technology for bridging the difficulties in electrochemical process, especially fuel cell energy conversion. AR technology is used as an accomplished tool of a conventional book, where students can learn deeply about the process, such as practicing steps and problem solving using animation. The implementation results show that the developed AR can help students enjoy to study fuel cell energy conversion, which means that the developed AR can support learning process effectively.
\end{abstract}

Keywords-Augmented reality, Fuel cell, Energy conversion

\section{Introduction}

Fuel cells are electrochemical cells that are able to convert hydrogen gas flows from anode to cathode through a membrane as an electricity source. This cell can be used as a large-scale power plant or small scale, for example for household purposes or commonly referred to as micro CHP (micro Combined Heat and Power) which is able to provide electricity and heat needs for households. Fuel cells can also be used in the automotive field. Brazil even tested a prototype bus fuel cell in 2009, whose fuel, hydrogen, is produced from electrolysis of water at a hydrogen gas production station. Honda also launched a hydrogen-powered car by applying fuel technology in their product Honda FCX in 2003. Deimler Chrysler in Europe has even launched the Clean Urban Transport for Europe (CUTE) project at the end of 2001 which promotes fuel 
cell buses operating in Amsterdam, Barcelona, Hamburg, London, Luxembourg, Madrid and Reykjavik (Iceland) [1].

In contrast to combustion-based energy technology, this technology is clean, because if hydrogen is used as fuel, carbon dioxide $(\mathrm{CO} 2)$ will not be produced as a byproduct of its production. Whereas if hydrocarbon fuels are used, which are sourced from fossil fuels, carbon dioxide will still be produced, but in quantities much lower than carbon dioxide produced by energy producing engines based on combustion technology. Related with the flexibility of fuels that can be used, the fuel cell is also declared as a sustainable technology, because in addition to relying on pure hydrogen gas as a fuel, this technology can also still use fossil fuels, such as methane gas, butane, ethanol, methanol and etc [2].

Figure 1 explains that in 2018, the results of the Energy Outlook review have shown changes in energy use. Energy transition in line with market developments in several developing countries. Energy demand in industrial sector is predicted increase almost doubled comparing to the demand in transportation sector in 2040 [3]. Meanwhile, the use of fuel oil still dominates until 2040. The good point is that the use of renewable energy is also increase. It shows the importance to introduce the alternative renewable energy, such as, fuel cells to be learned early on, especially by students. The fuel cell application is not only used on motor vehicles and power plants in households, but extends to electronic equipment such as cellular phones as well. In cellular phones fuel cells are used as batteries. Compared to lithium batteries, fuel cell batteries can life in 10 times more. That way, cellular phones can life a month without the need for additional battery power.

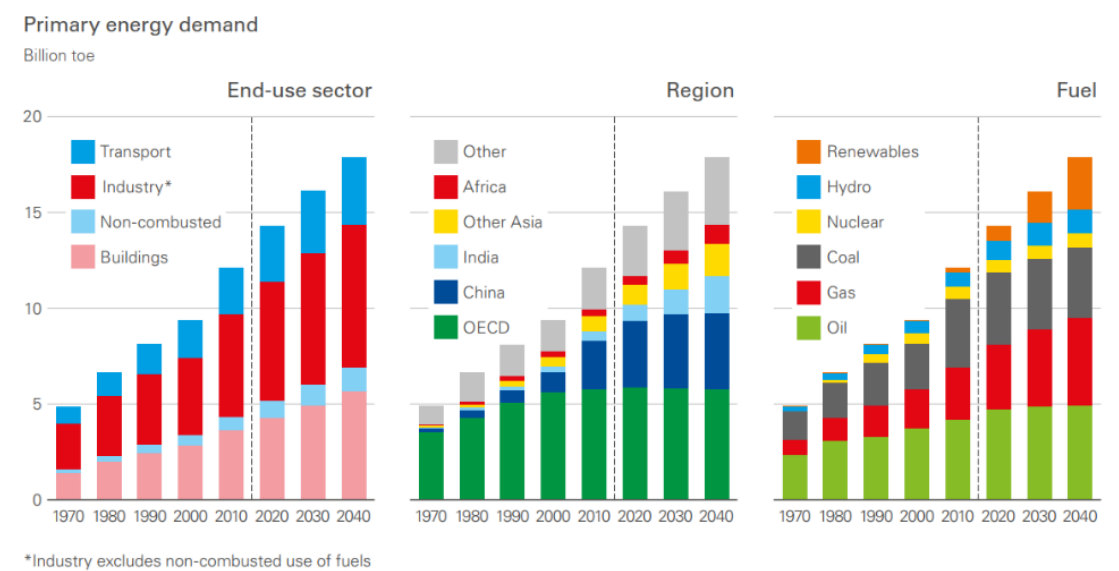

Fig. 1. Energy Demand per Sector and Region [3]

Some developed countries in the field of fuel cells, such as the US, Japan, and European countries like France, Germany, and the United Kingdom. Among the developed countries, Japan is the earliest to enter the commercial stage, namely for fuel cell fueled vehicles. This year Toyota has produced a fuel cell car that costs around 1 billion rupiahs. The United States has used fuel cells for buses, but has not yet reached 
the commercial stage because of the high cost of these components. However, in 19992000 the initial investment of fuel cell power plants was still five times that of BBM, and now it has reached twice that of conventional ones. As shown in Figure. 2 the fuel cells as renewable fuels needed.

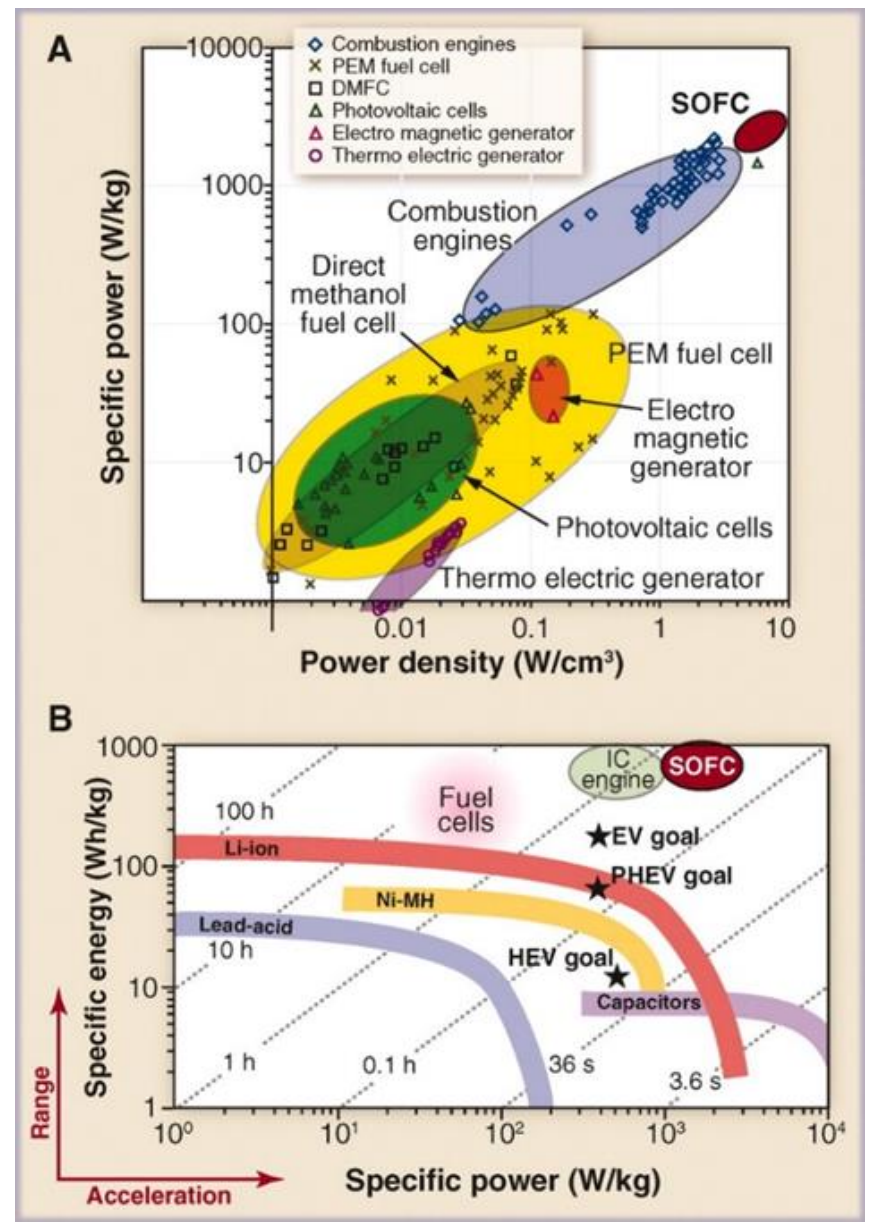

Fig. 2. The Fuel cells as Renewable Fuels needed [4]

In the long term, renewable energy sources will be very useful for increasing national needs. The data from the 2014 Indonesia Energy Outlook Book (OEI 2014) explains current energy problems and predictions of energy supply for the 2012-2035 period. Limited energy resources can cause total domestic energy production to be unable to meet domestic consumption by 2030 , so that Indonesia will become a 'net energy importer' country, meaning high dependence on an imports energy problem. As show in Figure. 3 it is evident from the information provide that final energy consumption in Indonesia in the period 2000-2012 increased by an average of $2.9 \%$ per year. The most dominant energy is the use of fuel oil including aviation fuel gas, natural gas, gasoline, 
kerosene, diesel oil, and fuel oil. The transportation sector is the biggest fuel user sector [5].

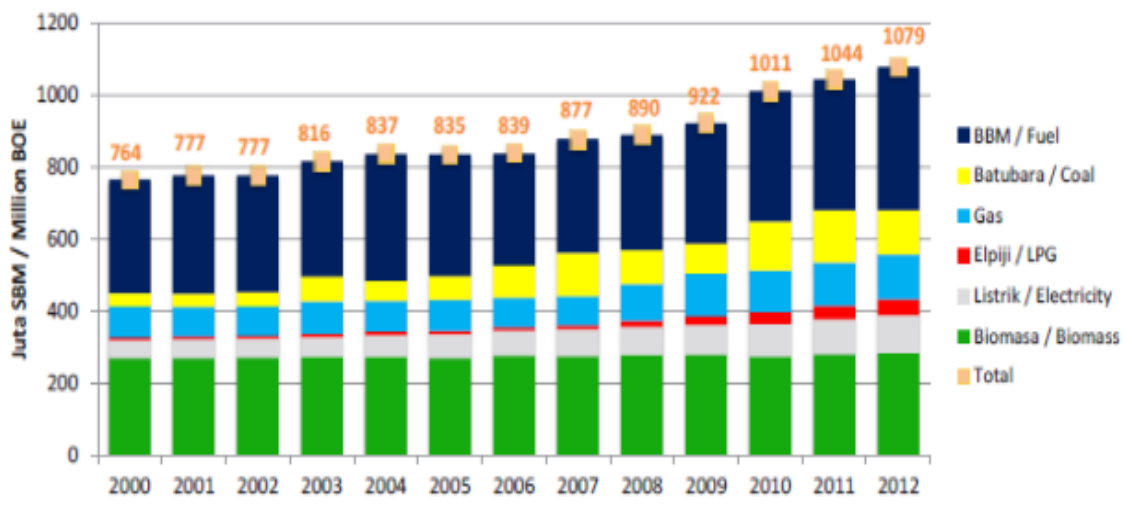

Fig. 3. Fuel consumption in Indonesia from 2000-2012 [6]

Figure. 3 shows a pattern of the energy consumption during 2000-2012, which is still dominated by fuel. During this time period, total fuel oil demand has escalated from 315 million Barrel Oil Equivalent (BOE) to 398 million BOE or increased 1.9\% per year as shown in Fig.3. In 2000, the largest share was obtained by diesel oil, i.e., 42\%, followed by kerosene and gasoline, which each fuel was reached $23 \%$, while fuel oil and aviation fuel were reached $10 \%$ and $2 \%$, respectively

Furthermore, in 2012 the fuel consumption was gradually transformed, i.e., gasoline and aviation were increased to $50 \%$ and $7 \%$, respectively, while diesel oil and kerosene were decreased to $37 \%$ and $4 \%$, respectively. This transformation show a pattern that fuel oil consumption has been changed. It is because the number of private vehicles is increased significantly, as well as the increase demand travelling with aircraft, so the pattern show the high rate of gasoline and aviation fuel. The substitution program of energy used by the industrial sector and households can also change the consumption pattern, that is, the use of the kerosene was substituted with liquefied petroleum gas (LPG). In 2000 to 2012, the coal consumption was escalated highly from 36.1 million BOE to 123 million BOE, which means that the demand was increased $9.9 \%$ per year. The coal is used to supply the industrial sector, such as cement, textile, and paper industries. In the same period, natural gas demand was also escalated from 87.2 million BOE to 125.3 million BOE. However, the average growth rate is still low, i.e., $2.8 \%$ per year, because of the limited of gas transmission and distribution infrastructure in industrial sector [6]. 


\section{Development of Fuel Cell Technology}

A fuel cell is an electricity power source that converts chemical energy into electrical energy using hydrogen as fuel and oxygen as an oxidant. The working principle of a fuel cell based on the combustion reaction is as follows [7], [8].

$$
2 \mathrm{H}_{2}+\mathrm{O}_{2} \rightarrow 2 \mathrm{H}_{2} \mathrm{O}
$$

Fuel cells promise electrical energy with high efficiency and are environmentally friendly. Unlike the fuel oil in the combustion process (combustion engine), fuel cells operate with high efficiency $(\sim 80 \%)$ [8]. Fuel cells provide electrical energy continuously as long as the hydrogen is supplied to it. The results of their chemical reactions are electricity, water and heat. The fuel cell consists of two layer as a pin output which is an anode and cathode the core layer is an electrolyte layer in the middle section as shown in Figure 4.

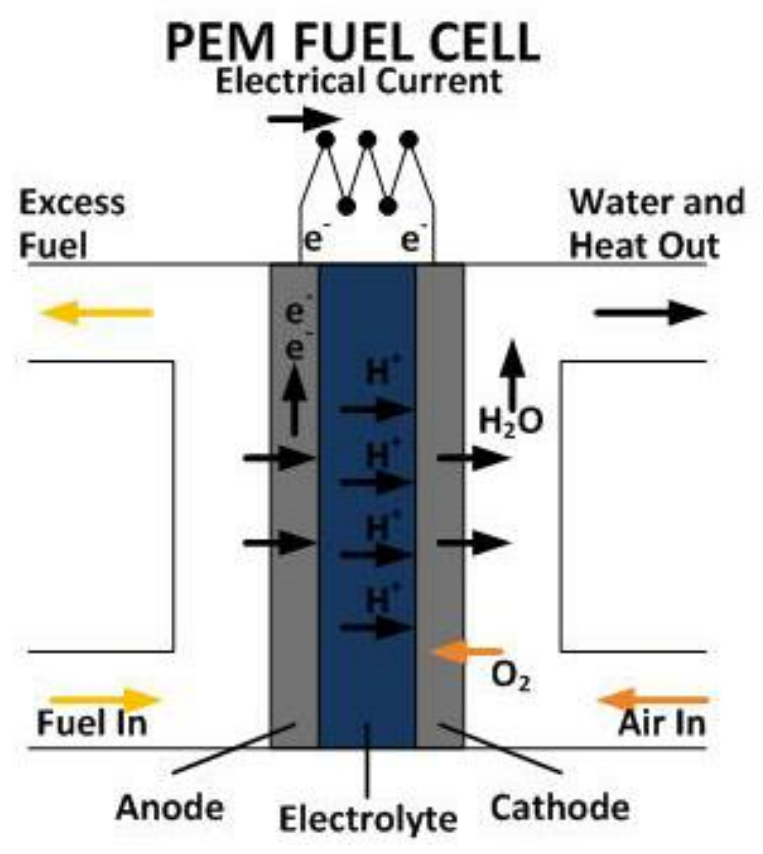

Fig. 4. Polymer electrolyte membrane fuel cells (PEMFC) in low temperatures

A fuel cell is in some aspects similar to a battery. It has electrolytes, and positive and negative electrodes, and generates direct electricity through electrochemical process. The different point is that a fuel cell needs a supply of fuel in the form of hydrogen and a constant supply of oxygen. The positive side is charged by protons, which move from anode through the membrane and move to the cathode [9]. The electrodes in the battery will reacted by chemical changes, while the electrodes in the fuel cells do not reacted chemical changes. Batteries that produce electricity through electrochemical reactions 
involve the materials in a battery. Therefore, batteries may run out when the materials conduct in the electrochemical reaction run out, while the fuel cell voltage will not run out as long as supply continuously.

\subsection{Various type of fuel cell}

There are various types of fuel cells depending on the electrolyte used. The following various type of fuel cells. First type is a fuel cell, which uses a membrane as its electrolyte called Polymer Electrolyte Membrane Fuel Cells (PEMFC). The temperature working has a range from 300C - 1000C [10]. The second type is a fuel cell, which uses methanol as the fuel. This fuel cell has a working temperature from 200C - 900C [11]. The third type uses liquid phosphoric acid as its electrolyte. The working temperature can reach to 2000C [12]. The fourth type uses molten, which combines lithium, sodium and potassium carbonate as the electrolyte. This type is called as MCFC, which can operate at high temperatures near to 6500C [13]. The last type is a fuel cell, which uses ceramic as its electrolyte. The working temperature range could be 5000C to $10000 \mathrm{C}$ [13], [14].

Some applications of fuel cells are use in transportation. Fuel cell on the vehicles may have new attractiveness with smaller vehicle designs and have more efficient capabilities than vehicles with other fuels [15]. Some automotive industries have developed two-wheeled vehicles and four-wheeled vehicles for vehicle designs purposes. Therefore, a large stationary fuel cells can generate electricity for home or business purposes. This fuel cell can also be interconnected with existing networks of the previous electricity. This type of fuel cell is very profitable for businesses and homes where electricity is not available. As an effective and renewable energy source, fuel cells can generate electricity as alternative choice for homes, hospitals and industries, for example some facilities such as servers or communications equipment, which require high-quality power, also can use this fuel cell. The use of this alternative energy can avoid power interruptions and interruptions in power supply, which may result in loss of important data or interruption of production processes.

\subsection{The urgency of introducing fuel cells in high school students}

Based on the explanation above about fuel cells, the availability of energy reserves, and also the energy needs in Indonesia in particular [16], it is necessary to increase awareness for the children of high school students to recognize renewable energy in the form of fuel cells. Certainly need a separate way to introduce fuel cell technology to high school students. One easy way is to use learning media. In this study, the learning media offered are in the form of fuel cell kits equipped with augmented reality technology.

\subsection{Augmented reality for fuel fells learning}

Augmented reality (AR) can be said as a technology used computer graphics representing real objects [17]. AR can also be translated as a technology that allows 
users to see the real world through virtual objects [18]. There are three aspects needed in designing AR, namely, a combination of real and virtual worlds; interactive relationships in real time; and 3D shape visualization. In addition to these three things, another thing to consider is portability or ability to be used in a wide range of motion space. AR displays visualization in the form of digital content over the media used through marker detection. AR technology, Virtual Learning Environment (VLE) and Mobile Learning (ML) are several technologies that can be integrated in learning [19][20]. This learning tools is able to create a new learning innovation environment that is more interesting and fun for high school students.

\section{$3 \quad$ Method}

The ADDIE models were used in this development research similar to life cycle developing process [21] as the basis for developing AR-based teaching materials. The following steps as a procedure applied in this development research in accordance with the ADDIE stages models as shown in Figure. 5.

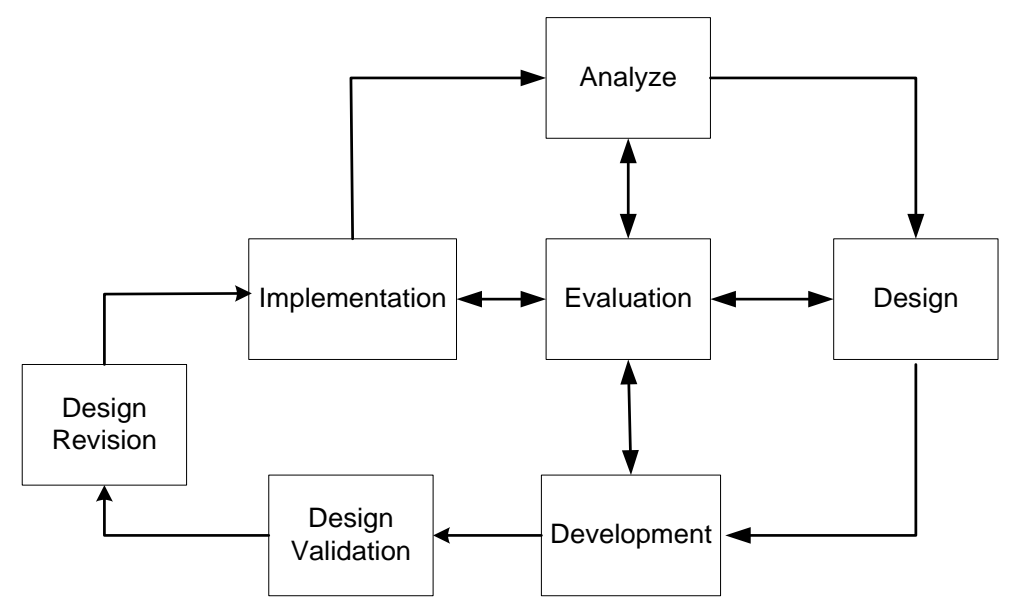

Fig. 5. Steps of the ADDIE Development Model

The developing of AR technology for introducing fuel cell is referred to the ADDIE model, which can be implemented to also develop a learning material. This model can be adopted as an organized process for developing learning materials. In this research, the developing AR technology can be used in both for conventional learning in class (face-to-face) and also online learning. The developed AR technology was carried out as illustrated in Figure. 5. The steps consist of the analysis, design, development, implementation, and evaluation phases. These steps were collaborated with the Sugiyono's model, i.e., an additional phase of product validation and product revision. Realization of developing AR technology was carried out with seven stages as follows. The first step is done by analyzing fuel cells based the needs of developing AR technology. The second step is to design AR application for smartphone as a learning 
media regarding to the form of material design, conventional or e-book as the supporting material design. The third step is to realize the design as developed media, i.e., AR application for fuel cell learning material. The fourth step is to validate the design and developed AR application for fuel cell, which is done by experts of media development and expert of learning material development. The fifth step is to revise while there are some revised comments given by experts. The sixth step is the implementation step, which can be associated with the implementation of the learning tools itself. This step is a trial implementation to deliver the AR application of fuel cell to selected students. The final step is the evaluation step, which evaluate the introducing process of the designed AR application to students.

\section{$4 \quad$ Result and Discussion}

The learning media of the fuel cell kits equipped with augmented reality technology are printed modules and ebook module that both are integrated with AR application. The AR content can be run on mobile applications and can be accessed offline, so the student can use the learning media independently inside or outside classroom. Figure.6 show implementation of learning media in mobile phone screen.

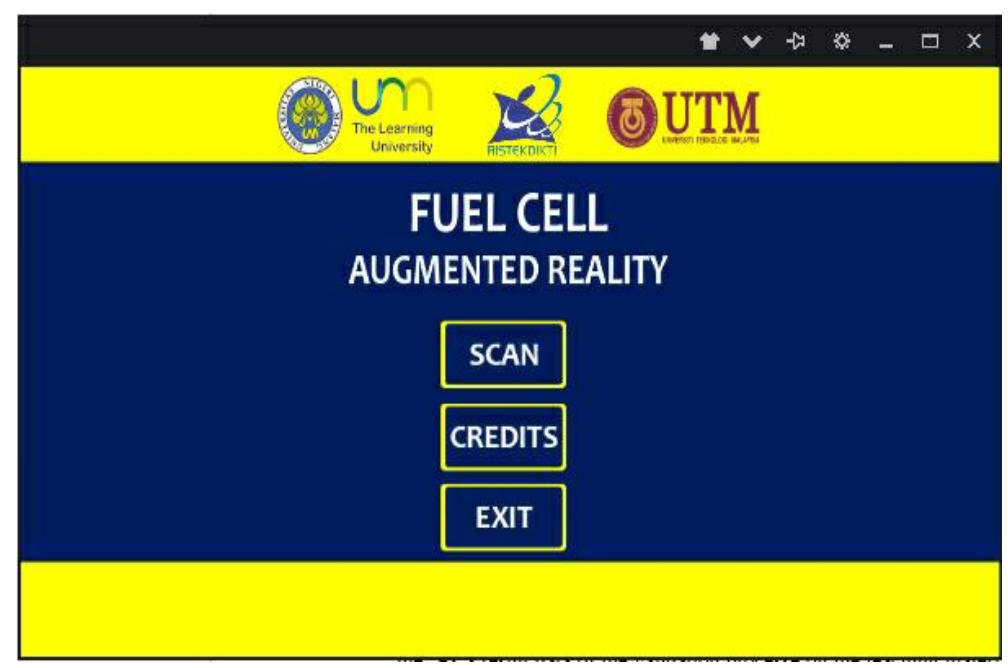

Fig. 6. Learning Media of The Fuel Cell Run in Mobile Phone

The AR application to introduce fuel cell as electrochemical energy conversion using smart phone camera. AR content appears when users scan appropriate markers contained in the module. Digital contents are displayed on smart phone screen in the form of video or animation illustrated the additional explanation related to the markers. Animation and Video contents, which appears when AR application is executed, are shown in Figure.7 and Figure.8. 


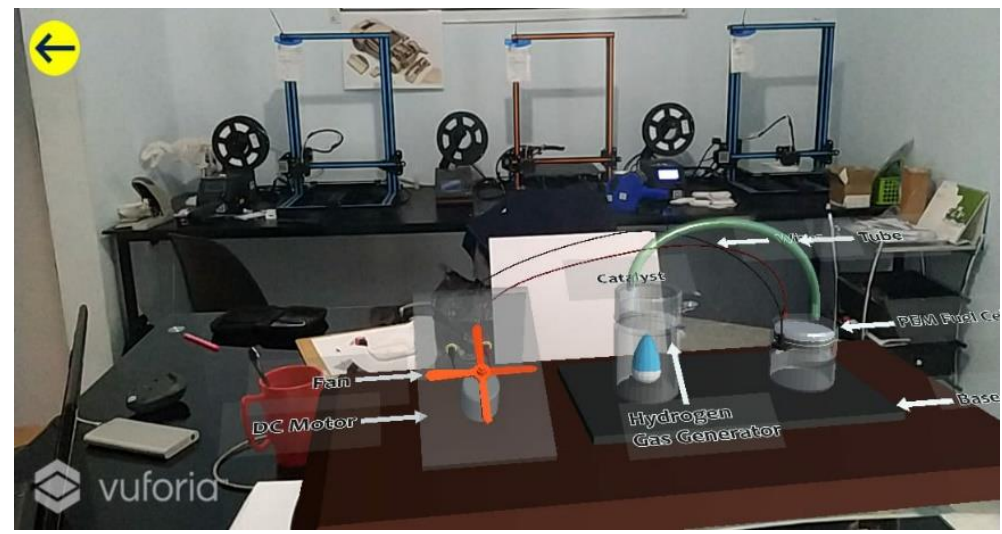

Fig. 7. Animation content shown in AR application in smart Phone

The PEMFC video content will play if the markers of the AR captured by the camera of the smart phone. The markers are designed are very unique to access AR application. This unique marker should be captured by the camera, so it can show reciprocal actions different with other markers. The contents appear on smart phone screen when the camera captures the appropriate markers. The pose and direction can affect, because the specific information about the parts of the PEMFC are imposed with many markers. When student attempt to catch the marker, it shows up with the video of the PEMFC content in the screen as shown in Figure 8. If the students have some difficulties to learn a part of fuel cell book, the students can use AR application by capturing markers in the book regarding the topic to view video or animation explained the detail explanation of the related part.

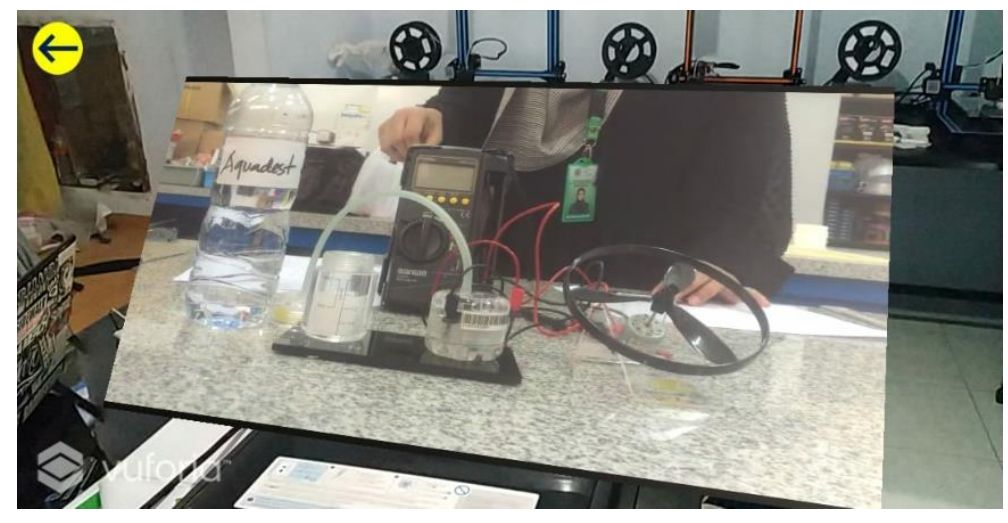

Fig. 8. Video content shown in AR application in smart Phone

As a result data of the validation processes on the teaching materials developed consisted of the validation on the media aspects and material aspects. The validation on media aspect is evaluated regarding to criteria needed for teaching materials, which 
consist of 1) appearance aspects, 2) preparatory aspects, 3) usage aspects, and 4) technical quality, as shown in Table 1.

Table 1. Media aspect Validation Result

\begin{tabular}{|l|c|c|c|}
\hline \multicolumn{1}{|c|}{ Criteria } & Obtained Score & Max Score & Percentage \\
\hline Appearance & 30 & 32 & $93.75 \%$ \\
\hline Preparatory & 8 & 8 & $100.00 \%$ \\
\hline Usage & 7 & 8 & $87.50 \%$ \\
\hline Technical Quality & 23 & 24 & $95.83 \%$ \\
\hline Average & 17 & 18 & $94.44 \%$ \\
\hline
\end{tabular}

After getting the media aspect, second step was done by the validation process of teaching materials, which was to observe material and content of AR application in PEMFC. The validation criteria for teaching materials aspect were divided into 1) preparatory aspects, 2) learning aspects, 3) content aspects, and 4) evaluation aspects. Table 2 describe the result of the material validation aspect.

Table 2. Material aspect Validation Result

\begin{tabular}{|l|c|c|c|}
\hline \multicolumn{1}{|c|}{ Criteria } & Obtained Score & Max Score & Percentage \\
\hline Preparatory & 8 & 8 & $100.00 \%$ \\
\hline Learning & 11 & 12 & $91.67 \%$ \\
\hline Content & 13 & 16 & $81.25 \%$ \\
\hline Evaluation & 11 & 12 & $91.67 \%$ \\
\hline Average & 10.75 & 12 & $89.58 \%$ \\
\hline
\end{tabular}

The scores were obtained based on the questionnaire filled by students who learned AR application of PEMFC in high school 1 of Malang. The several responses can be concluded as follows. The AR application of PEMFC can be categorized as feasible and interesting enough for learning fuel cell. This application can support teaching module, which guides students to learn fuel cell easily. Regarding the implementation process, students stated that this application is easy to be used and executed by students in senior high school level. The AR application was said easy to use, interesting, and can facilitate to learn fuel cell especially PEMFC. The summary of the implementation results to students is presented in Table 3.

Table 3. Real Implementation Test Result

\begin{tabular}{|l|c|c|c|}
\hline \multicolumn{1}{|c|}{ Criteria } & Obtained Score & Max Score & Percentage \\
\hline Appearance & 300 & 312 & $96.15 \%$ \\
\hline Preparatory & 297 & 312 & $95.19 \%$ \\
\hline Usage & 455 & 468 & $97.22 \%$ \\
\hline Technical Quality & 293 & 312 & $93.91 \%$ \\
\hline Average & 336.25 & 351 & $95.79 \%$ \\
\hline
\end{tabular}




\section{Conclusion}

The development of AR application of PEMFC can be realized as an application tool to support a learning of the fuel cell. AR application uses a technology that use a smart phone camera to display digital contents. The content can visualize the related processes through scanning the markers attached to the conventional book or e-book. Regarding to validation process, the developed AR application of PEMFC can be categorized as valid based experts questionnaire results with score of an average percentage $94.44 \%$ and $89.58 \%$, based the media and material aspects, respectively. The implementation process to student obtained $95.79 \%$, which can be concluded students can accept the content of AR application of PEMFC.

The AR technology continues to develop with a variety of simple and complex content, so that the fuel cell material as a relatively complex content can be updated along with the development aspect needs. The aspect may improve AR features in various aspects.

\section{Acknowledgement}

This research is supported partially by PNBP - IMRC (Indonesia-Malaysia Research Consortium) EDU KITS research collaboration Universitas Negeri Malang (UM) with Universiti Teknologi Malaysia (UTM).

\section{$7 \quad$ References}

[1] Andersen, O. (2007). Hydrogen as transport fuel in Iceland. The political, technological and commercial story of ECTOS. International Journal of Alternative Propulsion, 1(4), 339-351 https://doi.org/10.1504/ijap.2007.013328

[2] Rubrik Kimia, 'Majalah 1000 Guru', Fuel Cell: Teknologi Bersih yang Menjanjikan, Jan2011.

[3] Katie Mazerov, 'Drilling Contractor', Forecasts through 2050 suggest balanced mix of fuel sources while underscoring need for continued investments in hydrocarbons, 24-Oct-2018.

[4] Fuel Cell Handbook (Seventh Edition), page. 427.

[5] Hani Nur F., 'CNN Indonesia', Energi Baru Bukan Sekedar Untuk Industri, 15-Oct-2014.

[6] Badan Pengkajian dan Penerapan Teknologi, Indonesia Energy Outlook 2014.

[7] T. Jacob, 'Introduction to Fuel Cells', presented at the FHI Seminar, 14-Dec-2004.

[8] B. Cook, 'An Introduction To Fuel Cells And Hydrogen Technology', p. 31.

[9] Z. U. Bayrak and B. Gumus, "Dynamic simulation of a PEM fuel cell system Dynamic Simulation of a Pem Fuel Cell System," no. August, 2007. https://doi.org/10.1109/upec.20 $\underline{07.4469045}$

[10] D. Feroldi and M. Basualdo, 'Description of PEM Fuel Cells System', in PEM Fuel Cells with Bio-Ethanol Processor Systems, M. S. Basualdo, D. Feroldi, and R. Outbib, Eds. London: Springer London, 2012, pp. 49-72. https://doi.org/10.1007/978-1-84996-184-4_2

[11] A. Hards, 'Direct Methanol Fuel Cells', p. 10, 1996.

[12] H. Sotouchi, 'Phosphoric Acid Fuel Cells', p. 4.

[13] Eric D. Wachsman, Kang Taek Lee, 'Lowering the Temperature of Solid Oxide Fuel Cells'. 
[14] Mohamad, Z.F., 2011. The emergence of fuel cell technology and challenges for catchingup by latecomers: Insights from Malaysia and Singapore. International Journal of Technology and Globalisation, 5(3/4), pp.306-326. https://doi.org/10.1504/ijtg.2011.03976 $\underline{9}$

[15] Tanç, B., Arat, H.T., Baltacıoğlu, E. and Aydın, K., 2019. Overview of the next quarter century vision of hydrogen fuel cell electric vehicles. International Journal of Hydrogen Energy, 44(20), pp.10120-10128. https://doi.org/10.1016/j.ijhydene.2018.10.112

[16] The Green Lantern Project, 'Solid Oxide Fuel Cell: The Next Most Efficient, Economical, And Cleanest Energy Converter For Small Power Plant'.

[17] Pradibta, H., Nurhasan, U., Pramesti, T.D. and Suryadi, S.B., 2019, December. "Hijaiyah" interactive learning for pre-school students. In Journal of Physics: Conference Series (Vol. 1402, No. 6, p. 066050). IOP Publishing. https://doi.org/10.1088/1742-6596/1402/6/0660 $\underline{50}$

[18] R. Silva, J. C. Oliveira, and G. A. Giraldi, 'Introduction to Augmented Reality', p. 11.

[19] Y. Y. Joefrie, 'Teknologi Augmented Reality', no. 3, p. 10, 2011.

[20] Abdul Talib, Corrienna et al. Sakai: A Mobile Learning Platform. International Journal of Interactive Mobile Technologies (iJIM), [S.1.], v. 13, n. 11, p. pp. 95-110, nov. 2019. https ://doi.org/10.3991/ijim.v13i11.10800

[21] S. Sendari, D. Lestari, Y. Rahmawati and A. Prabowo, "Developing prototype of web-based home controlling for teaching trainer," 2016 IEEE Region 10 Symposium (TENSYMP), Bali, 2016, pp. 99-103, https://doi.org/10.1109/tenconspring.2016.7519385.

\section{Authors}

Siti Sendari is a lecture in the Electrical Engineering Program in the Department of Electrical Engineering, Faculty of Engineering, Universitas Negeri Malang, East JavaIndonesia. Research interest: Robotic, Artificial Intelligence, Study on Robustness and Adaptability of Genetic Network, Reinforcement Learning on Credit Branch Genetic Network Programming for Mobile Robots (siti.sendari.ft@um.ac.id)

Mahfud Jiono is a robotic and human-mechatronics scientist, electrical engineering educator, and lecture at Department of Electrical Engineering, Faculty of Engineering, Universitas Negeri Malang, East Java-Indonesia. He works also as a humanoid robot and mobile robot for ABU Robocon competition (mahfud.jiono.ft@um.ac.id)

Markus Diantoro is a Professor in the Department of Physics, Mathematics and Natural Sciences Faculty, Universitas Negeri Malang. His research interest Nanomaterials Synthesis, Materials Chemistry, Nanotechnology, Superconductivity, Crystal Magnetic Field, and Vortex. (markus.diantoro.fmipa@um.ac.id)

Heru Suryanto is a lecture at mechanical engineering, Department of Mechanical Engineering, Faculty of Engineering, Universitas Negeri Malang, East Java-Indonesia. The research topic: Natural fiber, Bionanocomposite, Nanomaterial, Composite material, and Material characterization (suryantoheru@yahoo.com)

Poppy Puspitasari is lecture at mechanical engineering, Department of Mechanical Engineering, Faculty of Engineering, Universitas Negeri Malang, East Java-Indonesia. She works also as researcher on Environmental, Nanomaterials, X-ray Diffraction, Synthesis, XRD, Materials Engineering, Materials Chemistry. (poppy@um.ac.id) 
Paper-Augmented Reality for Introducing Fuel Cell as Electrochemical Energy Conversion on...

Hadi Nur. He is a professor of chemistry at Universiti Teknologi Malaysia and an adjunct professor at Universitas Negeri Malang. Currently he work on Engineering, Green Chemistry, Materials Chemistry, Nanotechnology, and Materials Science (hadi@ibnusina.utm.my)

Article submitted 2020-04-14. Resubmitted 2020-05-24. Final acceptance 2020-05-25. Final version published as submitted by the authors. 